\title{
From where does "rete" in retina originate?
}

\author{
Paulus T. V. M. de Jong
}

Received: 19 July 2014 / Accepted: 30 July 2014 / Published online: 10 August 2014

(C) Springer-Verlag Berlin Heidelberg 2014

When we look up the word retina in the Oxford English Dictionary, we read: "a layer at the back of the eyeball that contains cells sensitive to light, which trigger nerve impulses that pass via the optic nerve to the brain, where a visual image is formed. Late Middle English: from Medieval Latin, from Latin rete 'net'." Retina is used as such for our sensory layer in the eye in Anglo-Saxon and some European countries, but the local word "net" appears in languages that have their own words for retina: Finnish (verkkokalvo); German (Netzhaut);

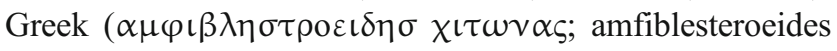
chitonas ); Letvian (tiklene); Lithuanian (tinklaine); Netherlands (netvlies); Norvegian (nethinnen); Polish (siatowka); Russian (cet atka; cjettsjatka); Slovakian (sietnice); Swedish (näthinnan), and Tschechian (sitnice). From now on I will often refer to this "net" as rete.

For many years I was puzzled about the origin of the rete component in retina, because I never observed macroscopically a net-like structure in the retina, except in some disorders such as peripheral drusen, flattened pigment epithelial detachments, retinitis pigmentosa or Sjögren's reticular dystrophy. The traditional etymology seems to fall short to explain the origin of the rete. So the aim of my research was to find out from where the rete element, in the word retina, could have come .

Presented at the 26th meeting of the Julius Hirschberg Gesellschaft, Zürich, Switzerland on 13-10-2012

P. T. V. M. de Jong $(\bowtie)$

Retinal Signal Processing, NIN KNAW Meibergdreef 47, Amsterdam, BA 1105, The Netherlands

e-mail: p.dejong@nin.knaw.nl

P. T. V. M. de Jong

Department of Ophthalmology, Academic Medical Center,

Amsterdam, The Netherlands

P. T. V. M. de Jong

Department of Ophthalmology, Leiden University Medical Center, Leiden, The Netherlands
The first description of the eye was made by Democritus around $450 \mathrm{BC}$ [1]. He drew two layers of the eye wall and the inner one, adjacent to the vitreous cavity, he named the Xít $u v$ $\mu \alpha \lambda\llcorner\sigma \tau \alpha \sigma o \mu \varphi \circ \varsigma$ (Chitoon malista somphos; yellow spongy tunic; Fig. 1) [1]. In Hippocratic times, 50 years later, the inner membrane that surrounded the v́ $\gamma \rho \mathrm{v}$ (hugron: the moist

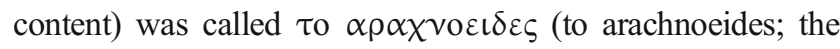
cobweb-like tunic). Does this mean that they detected a (cob)web structure and so indeed a rete? Could it be that they just wanted to indicate its gossamer structure? The latter seems possible, because Magnus wrote: "with which its delicate quality should be characterized."[1]. Herophilus used, around $300 \mathrm{BC}$, both the word arachnoeides and amfiblesteroeides for retina, due to the macroscopical comparison of the retina with an amfiblestron. According to Hirschberg, Herophilus chose amfiblesteroeides to indicate the interweaving of the retinal vessels and to express the form of the retina as a hoisted fishing net [2]. At the beginning of the Christian era, Celsus named it chitoon arachnoeides and also called the retina a "tenuissima tunica," (thinnest tunic) that formed a cavity in which the vitreous body is found [1]. A century later Rufus used both arachnoeides and amfiblesteroeides, and he mentioned that the arachnoeides was very delicate but also that the intertwining of the vessels had the appearance of a net [3]. Galen finally named in AD 200 the retina again amfiblesteroeides and left arachnoeides out [1]. For nearly 1000 years Galen dominated Western medicine. Galen's work, of whom not a single original manuscript survived, was translated from Greek by Katz and Duckworth $[4,5]$. According to Katz's translation, the cover of the vitreous is called by some people the net-shaped skin that looks like a net but does not resemble a skin [4]. In the corresponding Greek text of Galen in Katz's book, however, the word amfiblesteroeide chitona is written. So it seems to me that Katz also used rete as translation for amfiblestron, this particular usage having become well-established in the interim. Similarly, Duckworth wrote about the eye tunics: "and of the 

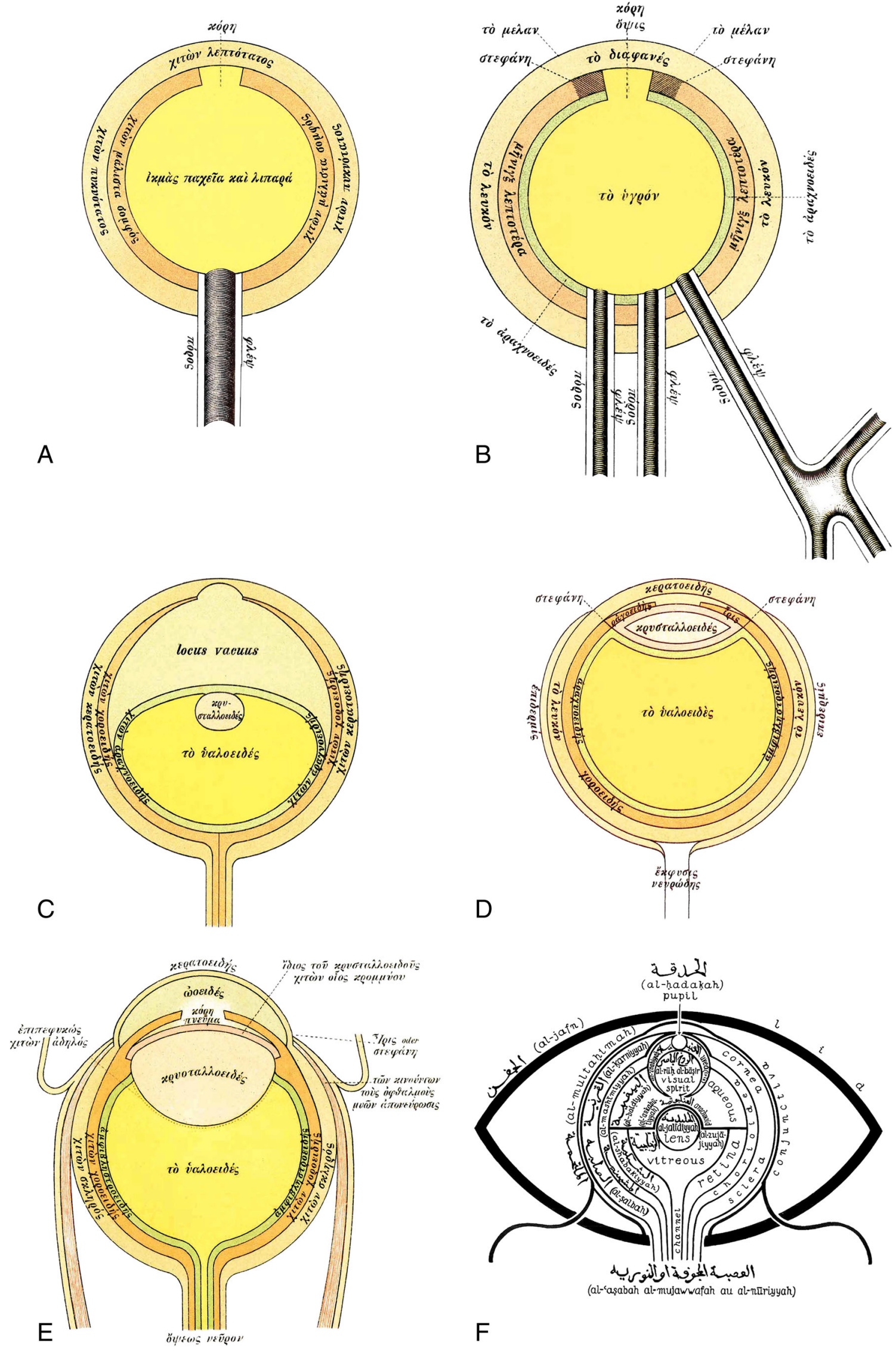
4 Fig. 1 Images of the eye (and descriptions of retinal layer) according to: (A.) Democritus (chitoon malista somfos; yellow spongy tunic); (B.) Hippocrates and Aristotle (to arachnoeides; the cobweb-like); (C.) Celsus (chitoon arachnoeides; cobweb-like tunic); (D.) Rufus (arachnoeides; ánd amfiblesteroeides; like a garment or fishing net); (E.) Galen (amfiblesteroeides); and (F.) Hunain Ibn Ishak (AD 860; al shabakkiyyah[11]). By courtesy of J.P.Wayenborgh [12].

third, which is called the net-like one [retina]. For the nerve which spreads itself out becomes in shape like a net."[5].

Dobson stated that Herophilus of Alexandria originally called the third tunic of the eye "arachnoid" but that he compared it to a casting net, and named it "retiform," a word from which our modern "retina" is derived."[6]. Dobson also mentioned Rufus stating that: "The third (tunic of the eye) encloses the "vitreous humour," its ancient name is "the arachnoid," and it is so called on account of its fineness; but since Herophilus compared it to a casting net, some authorities call it "retiform." As I intend to show, this might be too hasty a conclusion. Did Dobson simply follow Hirschberg, who used amfiblestroeides in this sense? [2]. As mentioned, Herophilus and Rufus used both arachnoeides and amfiblestroeides for the same layer [3]. Also the author of our first ophthalmic textbook, Aëtius of Amida, around AD 1500, translated amfiblesteroeide chitona as a casting net [7]. Avicenna wrote in his Canon "rescheth "which means "retiformis" and Gerardus Cremonensis translated this around 1150 into the new word retina [2].

One could think of four different etiologies for the rete at a time that no microscopes or magnifying glasses were available: a net of blood vessels, a net formed by the lens zonuli, a net due to entoptic phenomena, or to translational vagaries. Starting with the latter, we have seen that between $300 \mathrm{BC}$ and AD 200 the amfiblestroeides was used on and off for the retina and that Galen finally picked this name. Amfiblestroeides means: like an amfiblestron. Amfiblestron had around 400 BC seven meanings: (1.) Anything that is thrown round; (2.) Casting-net; (3.) The garment thrown like a net over Agamemnon; (4.) Shirt; (5.) Rags thrown around a body; (6.) Fetter, bond; and (7.) Encircling walls [8]. From these seven possible meanings of amfiblestron, the second one appears to have been chosen by subsequent translators, and it is my hypothesis that the arbitrary privileging of "casting-net" over other possible meanings such as a bond or a wall encircling the vitreous, launched the term on its career in this form.

As mentioned, older researchers thought that the retinal blood vessels looked like a rete [1]. The retinal vasculature can be holangiotic, merangiotic, paurangiotic, and anangiotic [9]. The horse retina is paurangiotic, but that of most animals well known to the Greeks, such as cows, goats, sheep, swine, and primates, it is holangiotic. Most of these retinas have a vessel pattern radiating from the optic disc and ,thus, seem more star-shaped than rete-shaped; the temporal arcade in the human retina might suggest, however, one ring within a net.
The view that rete originates from retinal vessels simulating a net, thus, remains a possibility.

At a certain time, it was assumed that the retina was a membrane enveloping the whole vitreous cavity, thus, also running before the lens, the organ of perception. Lens suspension fibres might have suggested a lace-like network. Already in the earliest drawings of the eye, the retina was drawn all around the vitreous cavity including the lens (Figure C). I think these fibres, that were not drawn in this figure, are a less plausible explanation. The same holds for entoptic phenomena due to leucocytes circulating in the capillaries around the macula, because these capillaries were not known as such around that time, and the retina only was indicated as the organ of perception by Platter around 1583 [10].

In conclusion, my hypothesis is that rete most likely originated from an arbitrary translation of amfiblestron as fishing or hunting net around $300 \mathrm{BC}$, and that this resulted via Arabic translation and retranslation in Neo-Latin into our word retina.

Acknowledgments Many thanks to P.G.Breen BA HDE, J.M.B.V.de Jong MD PhD, S.N.Meriwani MD, P.Saeed MD PhD, and P.Stoutenbeek MD for translation and critical comments.

The author certifies that he has no affiliations with or involvement in any organization or entity with any financial interest (such as honoraria; educational grants; participation in speakers' bureaus; membership, employment, consultancies, stock ownership, or other equity interest; and expert testimony or patent-licensing arrangements), or non-financial interest (such as personal or professional relationships, affiliations, knowledge or beliefs) in the subject matter or materials discussed in this manuscript.

\section{References}

1. Magnus H (1901) Die Augenheilkunde der Alten. Kern, Breslau pp $74-447$

2. Hirschberg J (1899) Die Anatomie des Auges bei den alten Griechen. Graefe-Saemisch Handbuch der gesamten Augenheilkunde 12:184-95

3. Daremberg C, Ruelle CE (1879) Oevres de Rufus d'Éphese. L'Imprimerie nationale, Paris pp 168-72

4. Katz O (1890) Die Augenheilkunde des Galenus. Inaugural Dissertation. Schade, Berlin, p 15

5. Duckworth WLH (1962) Galen on anatomical procedures. The later books translated by W.L.H.Duckworth. Cambridge university press, Cambridge, $\mathrm{p} 39$

6. Dobson JF (1925) Herophilus of Alexandria. Proc R Soc Med 18:19-32

7. Hirschberg J (2000) Die Augenheilkunde von Aëtius von Amida. Translated by Waugh RL, Wayenborgh, Oostende pp 2-3

8. Liddell HG, Scott R (1990) A Greek-English lexicon. Revised and augmented througout by Sir H.S.Jones with the assistance of R.McKenzie. Oxford university press, Oxford, p 90

9. Duke-Elder S (1958) The eyes of mammals. System of Ophthalmology Vol I. Kimpton, London pp 477-82

10. Platter F (1583) De corporis humani structura et usu. Vol. 3. Froben, Basel

11. Polyak SL (1941) The retina. The university of Chicago press, Chicago fig 7

12. Magnus H (1999) Ophthalmology of the ancients. Translated by Waugh RL. Vol 2. Wayenborgh, Oostende pp 461-469 